\title{
Assessment of microstructure stability and mechanical properties of X10CrWMoVNb9-2 (P92) steel after long-term thermal ageing for high-temperature applications
}

\author{
A. Zieliński ${ }^{1}$, G. Golański ${ }^{2 *}$, M. Sroka ${ }^{3}$ \\ ${ }^{1}$ Institute for Ferrous Metallurgy, K. Miarki 12, 44-100 Gliwice, Poland \\ ${ }^{2}$ Institute of Materials Engineering, Czestochowa University of Technology, \\ Armii Krajowej 19, 42-200 Czestochowa, Poland \\ ${ }^{3}$ Institute of Engineering Materials and Biomaterials, Silesian University of Technology, \\ Konarskiego 18a, 44-100 Gliwice, Poland
}

Received 6 July 2014, received in revised form 5 September 2014, accepted 17 February 2015

\begin{abstract}
This paper presents changes in mechanical properties and microstructure of the material of components of a power station boiler made of X10CrWMoVNb9-2 (P92) steel after long-term thermal ageing. Mechanical properties and microstructure were examined on material in initial heat treatment condition and after long-term thermal ageing up to $100,000 \mathrm{~h}$ at 600 and $650{ }^{\circ} \mathrm{C}$. The microstructure was observed using a scanning and transmission electron microscope. The examinations of steel microstructure and mechanical properties in initial heat treatment condition have confirmed that the requirements for this steel are met. Longterm thermal ageing at a temperature similar to the operating one as well as mechanical properties and microstructure examinations allowed to assess the effect of long-term impact of temperature on the properties and microstructure of P92 steel. The presented method can be used for evaluation and qualification of microstructural changes in power station boiler components operating under creep conditions.
\end{abstract}

K e y w or d s: P92 steel, microstructure, mechanical properties, long-term thermal ageing

\section{Introduction}

The long-term impact of elevated temperature during the operation of pressure equipment and systems brings about changes in microstructure and mechanical properties of their material. These changes determine the lifetime of components, which are now usually designed for 200,000 h of operation. However, it does not mean that failure-free operation is ensured for such a long time. Therefore, diagnostic works and inspections, and possible repairs are carried out during boiler operation to ensure safe and failure-free operation of power units [1-5].

The condition assessment of power system components requires comprehensive testing and measurements from time to time, and their selection depends on the type and working conditions of an analysed component as well as the possibility of access to the examined component. This assessment is made based on destructive and non-destructive materials testing, and the obtained results are referred to the material characteristics of given steel after an operation. To make such an assessment, a database of characteristics of changes in microstructure and mechanical properties of the examined materials with various degrees of degradation is necessary [6-10]. The use of such a procedure allows good evaluation of the material condition and its exhaustion degree and determination of the time of further safe operation until the next inspection. This paper presents selected characteristics of mechanical properties and analysis of changes in the microstructure of X10CrWMoVNb9-2 (P92) steel after long-term thermal ageing at 600 and $650^{\circ} \mathrm{C}$.

*Corresponding author: tel.: +48 343250 721; fax: +48 343250 721; e-mail address: grisza@wip.pcz.pl 
Table 1. Chemical composition of the examined X10CrWMoVNb9-2 (P92) steel

\begin{tabular}{cccccccccccc}
\hline \multicolumn{11}{c}{ Chemical composition (mass\%) } \\
\hline $\mathrm{C}$ & $\mathrm{Mn}$ & $\mathrm{Si}$ & $\mathrm{P}$ & $\mathrm{S}$ & $\mathrm{Cr}$ & $\mathrm{Mo}$ & $\mathrm{V}$ & $\mathrm{W}$ & $\mathrm{Nb}$ & $\mathrm{B}$ & $\mathrm{N}$ \\
0.10 & 0.45 & 0.17 & 0.01 & 0.01 & 9.26 & 0.47 & 0.20 & 1.95 & 0.059 & 0.009 & 0.04 \\
\hline
\end{tabular}

\section{Test sample and research methodology}

The test sample was X10CrWMoVNb9-2 (P92) steel in the form of a pipe section with a diameter of $160 \mathrm{~mm}$ and wall thickness of $40 \mathrm{~mm}$ in initial heat treatment condition and after long-term thermal ageing at 600 and $650{ }^{\circ} \mathrm{C}$ and soaking times of up to $100,000 \mathrm{~h}$. The chemical composition of the examined steel regarding the requirements EN 10216-2 [11] is summarised in Table 1.

The examinations of mechanical properties of P92 steel in an initial heat treatment condition and after long-term thermal ageing included performance of the following: static tensile test at room and elevated temperatures using Zwick testing machine with $200 \mathrm{kN}$ capacity of the testing system, hardness measurement by Vickers method with Future - Tech FM - 7 hardness testing machine using indenter load of $10 \mathrm{~kg}$; the impact test was carried out on standard $\mathrm{V}$-notched test samples. The microstructure examination was carried out using Inspect F scanning electron microscope (SEM) on conventionally prepared metallographic micro sections etched with ferric chloride and TITAN 80-300 transmission electron microscope (TEM) using thin foils. The analysis of precipitation processes was carried out by an X-ray analysis of carbide isolates with Philips diffractometer and using thin foils for selective electron diffraction.

\section{Microstructure and properties of P92 steel in initial heat treatment condition}

In its initial heat treatment condition, the P92 steel was characterised by the microstructure with the predominating share of tempered lath martensite with high-density dislocation, and also polygonised substructure of ferrite grain was observed (Fig. 1). P92 steel is characterised by microstructure typical for this group of steels $[1,3,5,8,9]$. The precipitate identification revealed the existence of the following precipitates in the examined steel in initial heat treatment condition: $\mathrm{MX}$ and $\mathrm{M}_{23} \mathrm{C}_{6}$. The examples of morphologies of these precipitates are shown in Figs. 2 and 3. The MX precipitates were observed inside martensite laths, at dislocations and on the subgrain boundaries. On the other hand, $\mathrm{M}_{23} \mathrm{C}_{6}$ carbides were mainly revealed at the former austenite grain boundaries and the martensite lath boundaries. The results of iden-
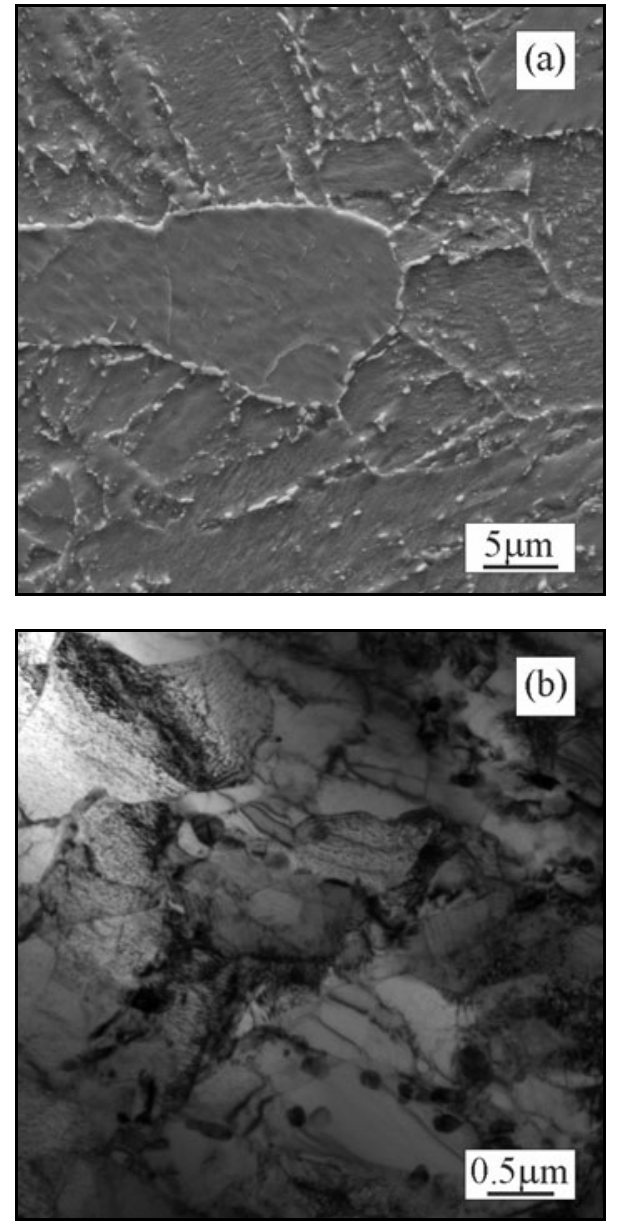

Fig. 1. The microstructure of P92 steel in initial heat treatment condition: a) SEM; b) TEM, thin foil.

tification carried out by selective electron diffraction method with TEM (Figs. 2, 3) found their confirmation in tests carried out by X-ray analysis of carbide isolates (Table 2).

Mechanical properties of P92 steel in an initial heat treatment condition determined at room and elevated temperatures are presented in Tables 3 and 4 .

The examinations of mechanical properties of P92 steel in an initial heat treatment condition at room and elevated temperatures $\left(600\right.$ and $650^{\circ} \mathrm{C}$ ) have revealed that properties of the examined steel comply with the requirements for this grade of steel. In its initial heat treatment condition, P92 steel was characterised by high mechanical properties: yield point and 

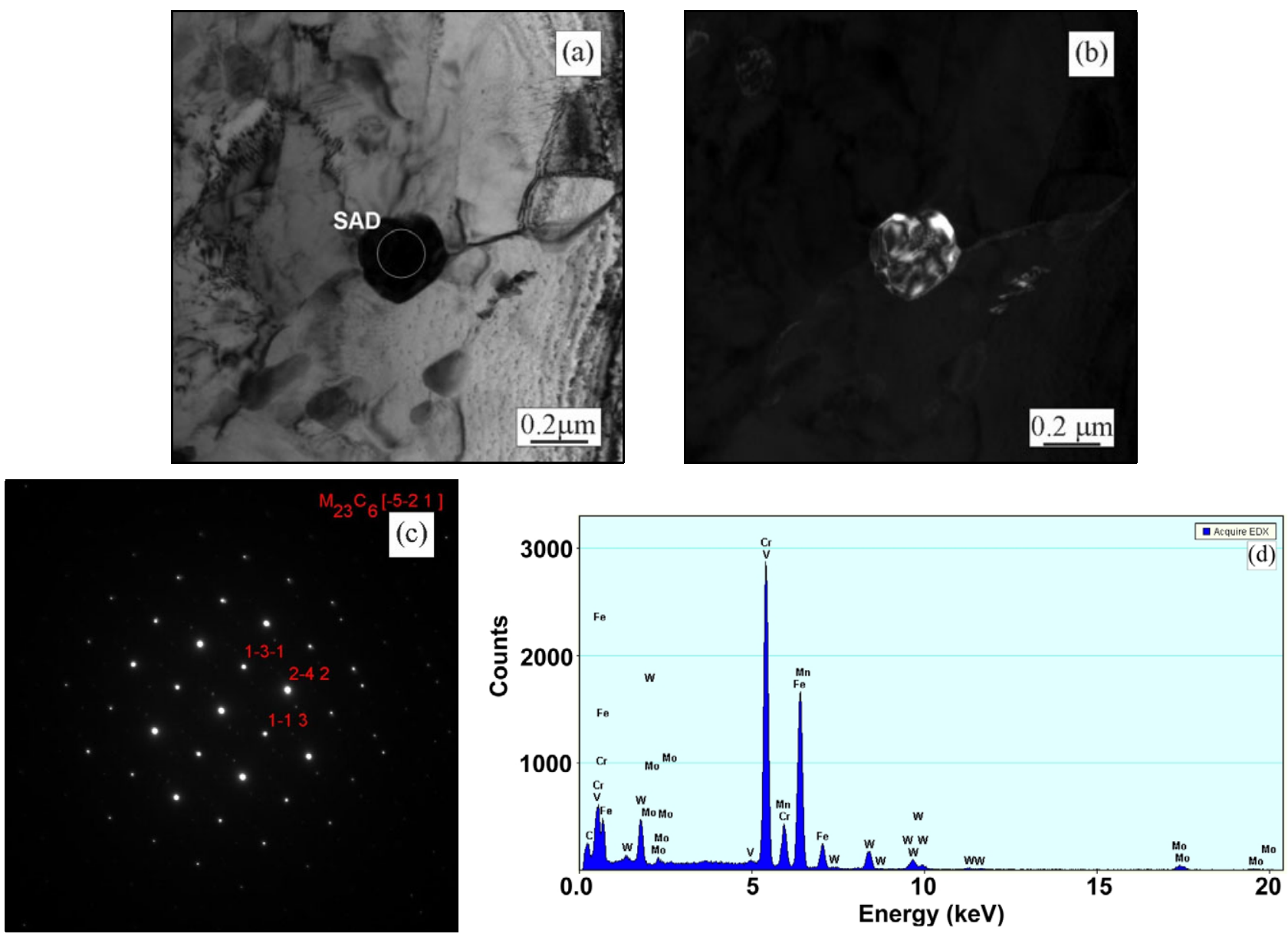

Fig. 2. Morphology of $\mathrm{M}_{23} \mathrm{C}_{6}$ precipitates in $\mathrm{P} 92$ steel in initial heat treatment condition: a) bright field, b) dark field, c) resolved electron diffractogram of $\mathrm{M}_{23} \mathrm{C}_{6}$ phase, d) EDS analysis of $\mathrm{M}_{23} \mathrm{C}_{6}$ phase.

Ta b l e 2. X-ray phase analysis of precipitates in P92 steel in initial heat treatment condition and after long-term thermal ageing

\begin{tabular}{|c|c|c|c|}
\hline Material condition & Phase components & Material condition & Phase components \\
\hline $\begin{array}{c}\text { Initial heat } \\
\text { treatment condition }\end{array}$ & \multicolumn{3}{|c|}{$\mathrm{M}_{23} \mathrm{C}_{6}$ - main phase; $\mathrm{MC}$ - traces } \\
\hline $1,000 \mathrm{~h} / 600^{\circ} \mathrm{C}$ & $\begin{array}{c}\mathrm{M}_{23} \mathrm{C}_{6}-\text { main phase } \\
\mathrm{Fe}_{2}(\mathrm{Mo}, \mathrm{W})-\text { small amounts } \\
\mathrm{MC}-\text { traces }\end{array}$ & $1,000 \mathrm{~h} / 650^{\circ} \mathrm{C}$ & $\begin{array}{c}\mathrm{M}_{23} \mathrm{C}_{6}-\text { main phase } \\
\mathrm{Fe}_{2}(\mathrm{Mo}, \mathrm{W})-\text { small amounts } \\
\mathrm{MC}-\text { traces }\end{array}$ \\
\hline $10,000 \mathrm{~h} / 600^{\circ} \mathrm{C}$ & $\begin{array}{c}\mathrm{M}_{23} \mathrm{C}_{6}-\text { main phase } \\
\mathrm{Fe}_{2}(\mathrm{Mo}, \mathrm{W})-\text { small amounts } \\
\mathrm{MC}-\text { traces }\end{array}$ & $10,000 \mathrm{~h} / 650^{\circ} \mathrm{C}$ & $\begin{array}{c}\mathrm{M}_{23} \mathrm{C}_{6}-\text { main phase } \\
\mathrm{Fe}_{2}(\mathrm{Mo}, \mathrm{W})-\text { small amounts } \\
\mathrm{MC}-\text { traces }\end{array}$ \\
\hline $70,000 \mathrm{~h} / 600^{\circ} \mathrm{C}$ & $\begin{array}{c}\mathrm{M}_{23} \mathrm{C}_{6}-\text { main phase } \\
\mathrm{Fe}_{2}(\mathrm{Mo}, \mathrm{W})-\text { small amounts } \\
\mathrm{MC}-\text { traces } \\
\text { Probably } \mathrm{MC} \text { carbide containing } \\
\text { mainly } \mathrm{Cr}-\text { phase } \mathrm{Z}\end{array}$ & $70,000 \mathrm{~h} / 650^{\circ} \mathrm{C}$ & $\begin{array}{c}\mathrm{M}_{23} \mathrm{C}_{6}-\text { main phase } \\
\mathrm{Fe}_{2}(\mathrm{Mo}, \mathrm{W})-\text { small amounts } \\
\mathrm{MC}-\text { traces }\end{array}$ \\
\hline $100,000 \mathrm{~h} / 600^{\circ} \mathrm{C}$ & $\begin{array}{c}\mathrm{M}_{23} \mathrm{C}_{6}-\text { main phase } \\
\mathrm{Fe}_{2}(\mathrm{Mo}, \mathrm{W})-\text { small amounts } \\
\mathrm{MC}-\text { traces }\end{array}$ & $100,000 \mathrm{~h} / 650^{\circ} \mathrm{C}$ & $\begin{array}{c}\mathrm{M}_{23} \mathrm{C}_{6}-\text { main phase } \\
\mathrm{Fe}_{2}(\mathrm{Mo}, \mathrm{W})-\text { small amounts } \\
\mathrm{MC}-\text { traces }\end{array}$ \\
\hline
\end{tabular}



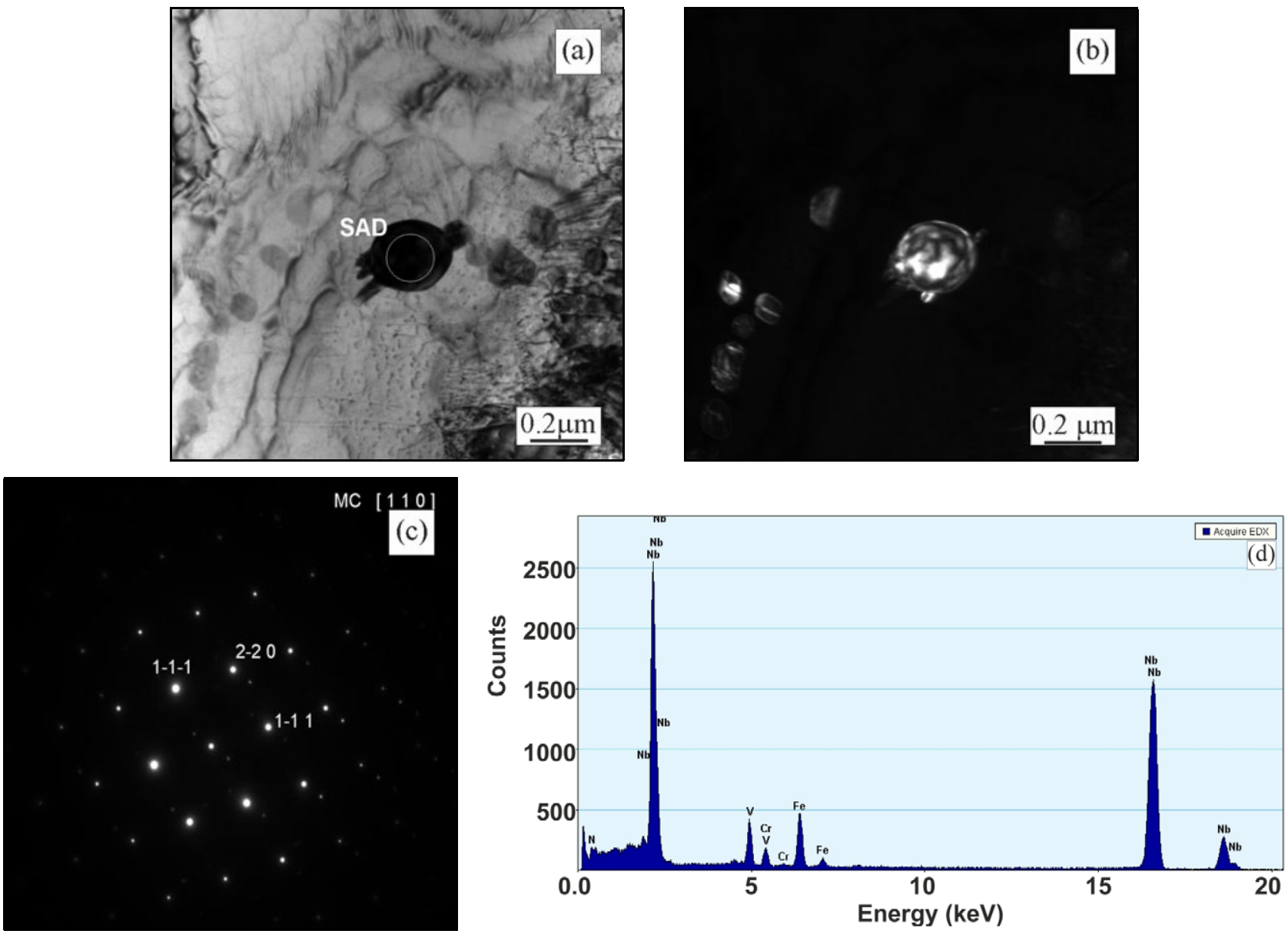

Fig. 3. Morphology of MC precipitates in P92 steel in initial heat treatment condition: a) bright field, b) dark field, c) resolved electron diffractogram of MC phase, d) EDS analysis of MC phase.

Table 3. Mechanical properties of P92 steel in initial heat treatment condition determined at room temperature, along with the required ones according to [11]

\begin{tabular}{ccccc}
\hline YS (MPa) & TS (MPa) & Elongation (\%) & KV (J) & HV10 \\
\hline 562 & 735 & 19 & 161 & 225 \\
min. 440 & min. 620 & min. 17 & min. 27 & - \\
\hline
\end{tabular}

Table 4. Mechanical properties of P92 steel in initial heat treatment condition determined at elevated temperatures 600 and $650^{\circ} \mathrm{C}$, along with the required ones according to $[11]$

\begin{tabular}{|c|c|c|c|}
\hline \multicolumn{4}{|c|}{ Temperature $\left({ }^{\circ} \mathrm{C}\right)$} \\
\hline \multicolumn{2}{|c|}{600} & \multicolumn{2}{|c|}{650} \\
\hline YS (MPa) & $\mathrm{TS}(\mathrm{MPa})$ & $\mathrm{YS}(\mathrm{MPa})$ & $\mathrm{TS}(\mathrm{MPa})$ \\
\hline 270 & 290 & 190 & 200 \\
\hline \multicolumn{2}{|c|}{$\mathrm{YS}_{\min }^{600}=248 \mathrm{MPa}$} & \multicolumn{2}{|c|}{-} \\
\hline
\end{tabular}

tensile strength were higher than the required minimum value by 13 and $19 \%$, respectively. Impact energy of P92 steel in initial heat treatment condition was approx. 6 times as high as the required minimum value of $27 \mathrm{~J}$. High impact energy of creep-resisting steel in initial heat treatment condition is required because, as shown by experience, during the operation of steel under creep conditions there is a faster decrease in impact energy as compared to other mechanical properties $[8,12,13]$.

\section{Microstructure and properties of P92 steel after long-term thermal ageing}

The examinations of P92 steel after ageing at 600 and $650{ }^{\circ} \mathrm{C}$ and after up to $5,000 \mathrm{~h}$ revealed no essential changes in microstructure (Fig. 4).

Longer times of thermal ageing of P92 steel contribute to an absolute increase in the amount and size of precipitates at the former austenite grain boundaries and to a gradual degradation of tempered martensite lath microstructure (Fig. 5). As revealed by X-ray phase analysis (Table 2), Laves phase ap- 

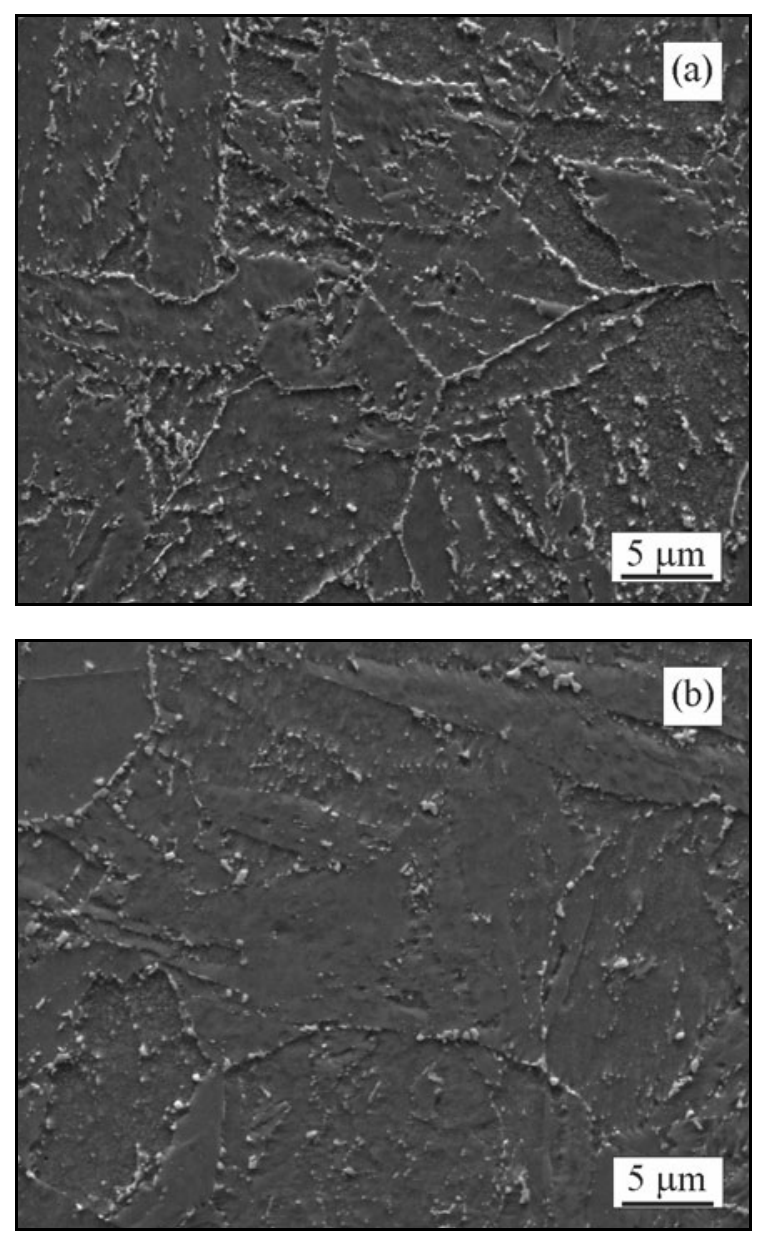

Fig. 4. The microstructure of $\mathrm{P} 92$ steel after $5,000 \mathrm{~h}$ ageing at a) $600{ }^{\circ} \mathrm{C}$; b) $650{ }^{\circ} \mathrm{C}$, SEM.

pears in the microstructure. Laves phase in the examined steel was observed mainly at the grain/lath boundaries, nearby $\mathrm{M}_{23} \mathrm{C}_{6}$ carbides.

The extension of the time of thermal ageing up to $70,000 \mathrm{~h}$ resulted in partial degradation of lath microstructure of tempered martensite areas for a test temperature of $600^{\circ} \mathrm{C}$ (Fig. 6a). For the ageing temperature of $650^{\circ} \mathrm{C}$, further progressing decomposition of lath martensite microstructure was observed (Fig. 6b). This microstructure was characterised by a still preserved martensitic microstructure with numerous different size precipitates at the former austenite grain and martensite lath boundaries. In both of the analysed microstructures, areas were observed where some precipitates at the grain boundaries were so high that they formed the so-called continuous network of precipitates.

The microstructure of P92 steel observed after $100,000 \mathrm{~h}$ ageing at test temperatures shows further gradual degradation of lath microstructure of tempered martensite areas and advanced precipitation processes, especially at the former austenite grain
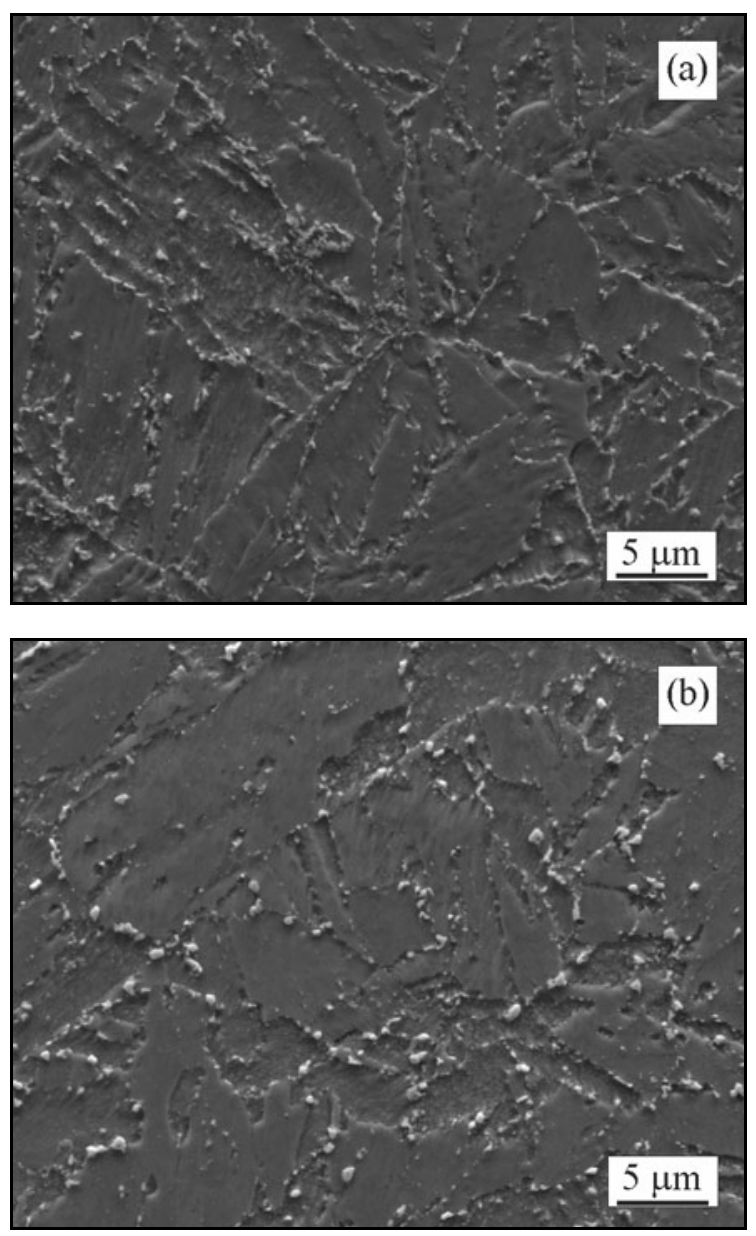

Fig. 5. The microstructure of P92 steel after 10,000 h ageing at a) $600{ }^{\circ} \mathrm{C}$; b) $650{ }^{\circ} \mathrm{C}, \mathrm{SEM}$.

boundaries, resulting in the formation of the so-called continuous network of precipitates. The degradation processes of tempered martensite lath microstructure were more advanced for the examined material after long-term thermal ageing at $650^{\circ} \mathrm{C}$ (Figs. 7, 8). An increase in the size of precipitates was revealed, which unambiguously indicated the occurring precipitation coarsening process (Figs. 7, 8). More advanced microstructure degradation processes were observed in the steel annealed at $650^{\circ} \mathrm{C}$. Similar results of microstructural degradation in $9 \% \mathrm{Cr}$ steel were also observed in $[14,15]$. Moreover, the analysis of the microstructure of P92 steel after thermal ageing revealed the existence of near-boundary precipitate-depleted zones (Fig. 7). This type of microstructural degradation is commonly observed in the case of low-alloy steels for the power industry $[16,17]$. According to researchers [16-18], the occurrence of this zone is related to precipitation processes and the increase in particles on the grain boundaries. The width of this zone depends not only on the operating parameters of steel but also on its chemical composition. As shown by lit- 

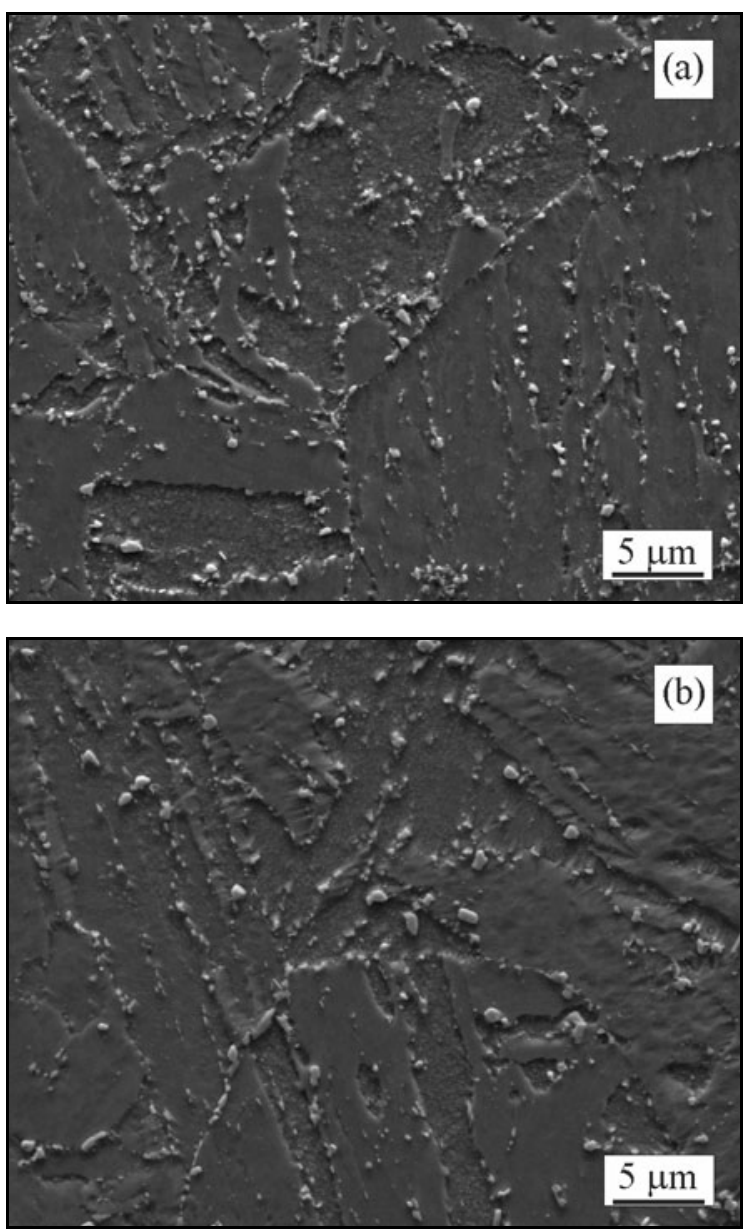

Fig. 6. The microstructure of $\mathrm{P} 92$ steel after $70,000 \mathrm{~h}$ ageing at a) $600^{\circ} \mathrm{C}$; b) $650^{\circ} \mathrm{C}, \mathrm{SEM}$.

erature data $[17,19,20]$, the existence of precipitatedepleted zones in metallic alloys results not only in a reduction in a value of yield point or tensile strength
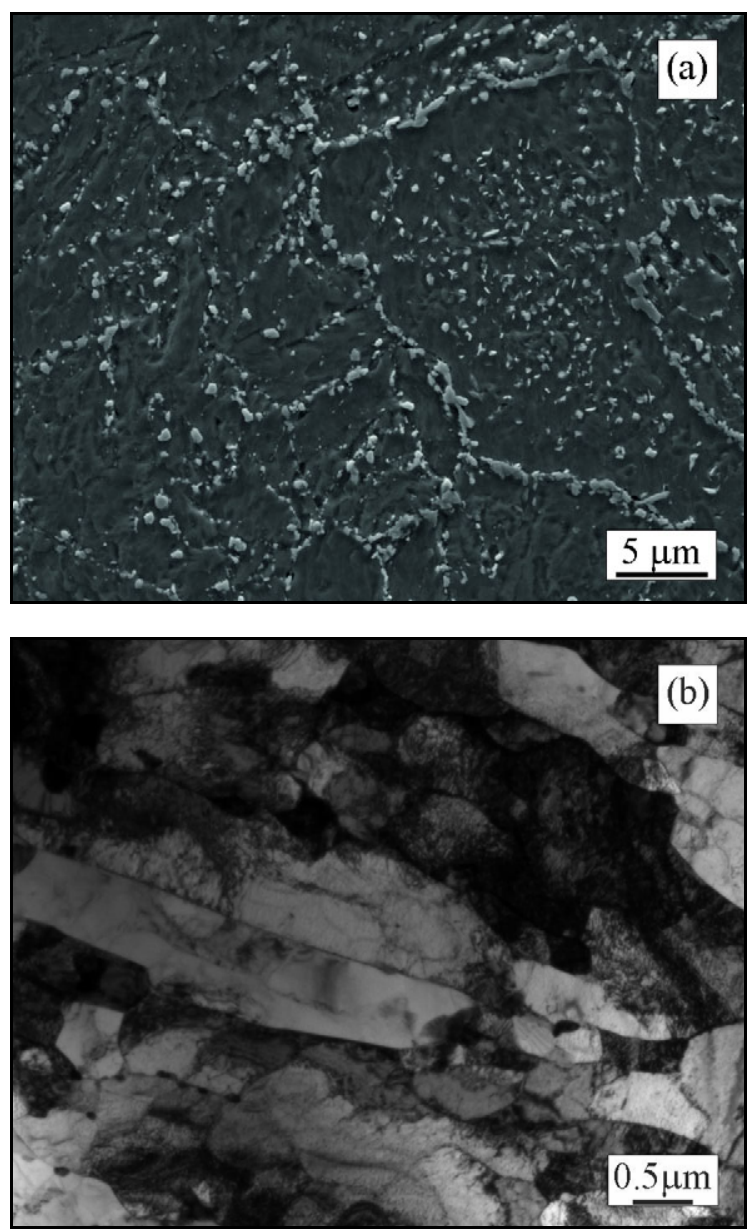

Fig. 7. The microstructure of P92 steel after 100,000 h ageing at $600^{\circ} \mathrm{C}$, a) SEM, b) TEM.

but also in a decrease in creep strength.

In addition to degradation of tempered martensite lath microstructure and increase in the amount
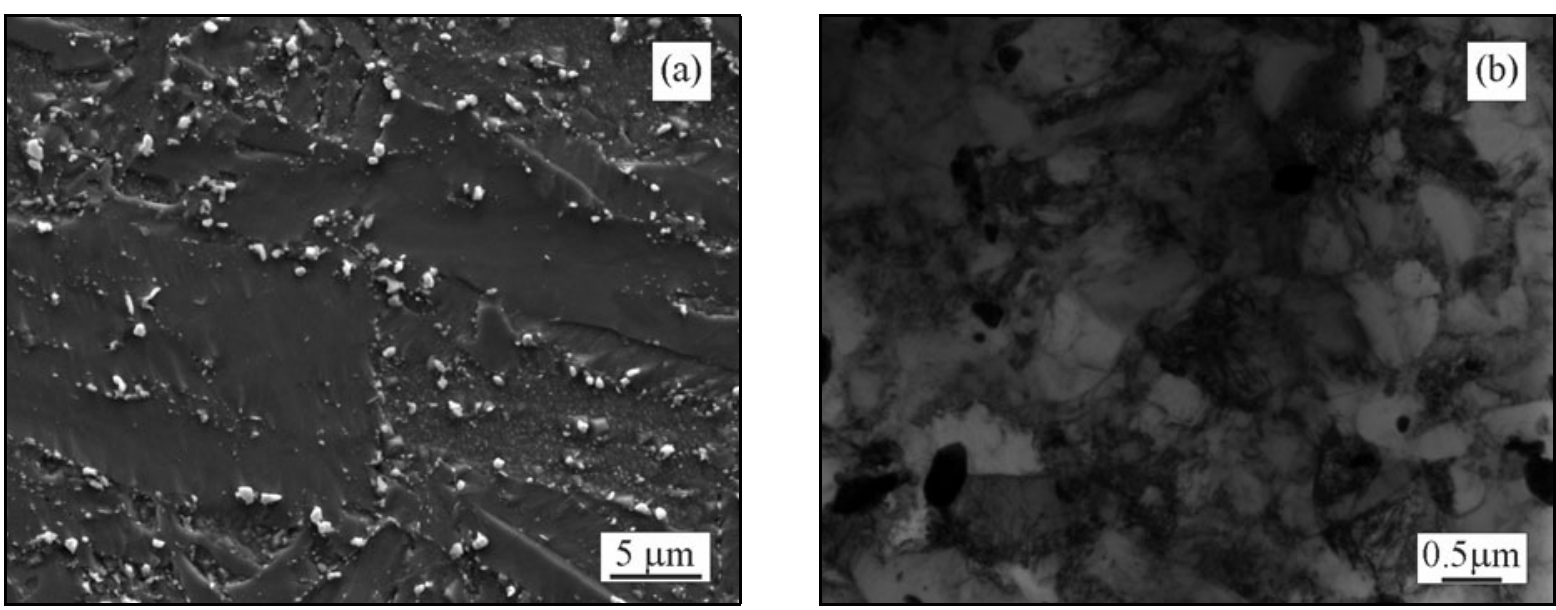

Fig. 8. The microstructure of $\mathrm{P} 92$ steel after $100,000 \mathrm{~h}$ ageing at $650^{\circ} \mathrm{C}$, a) SEM, b) TEM. 

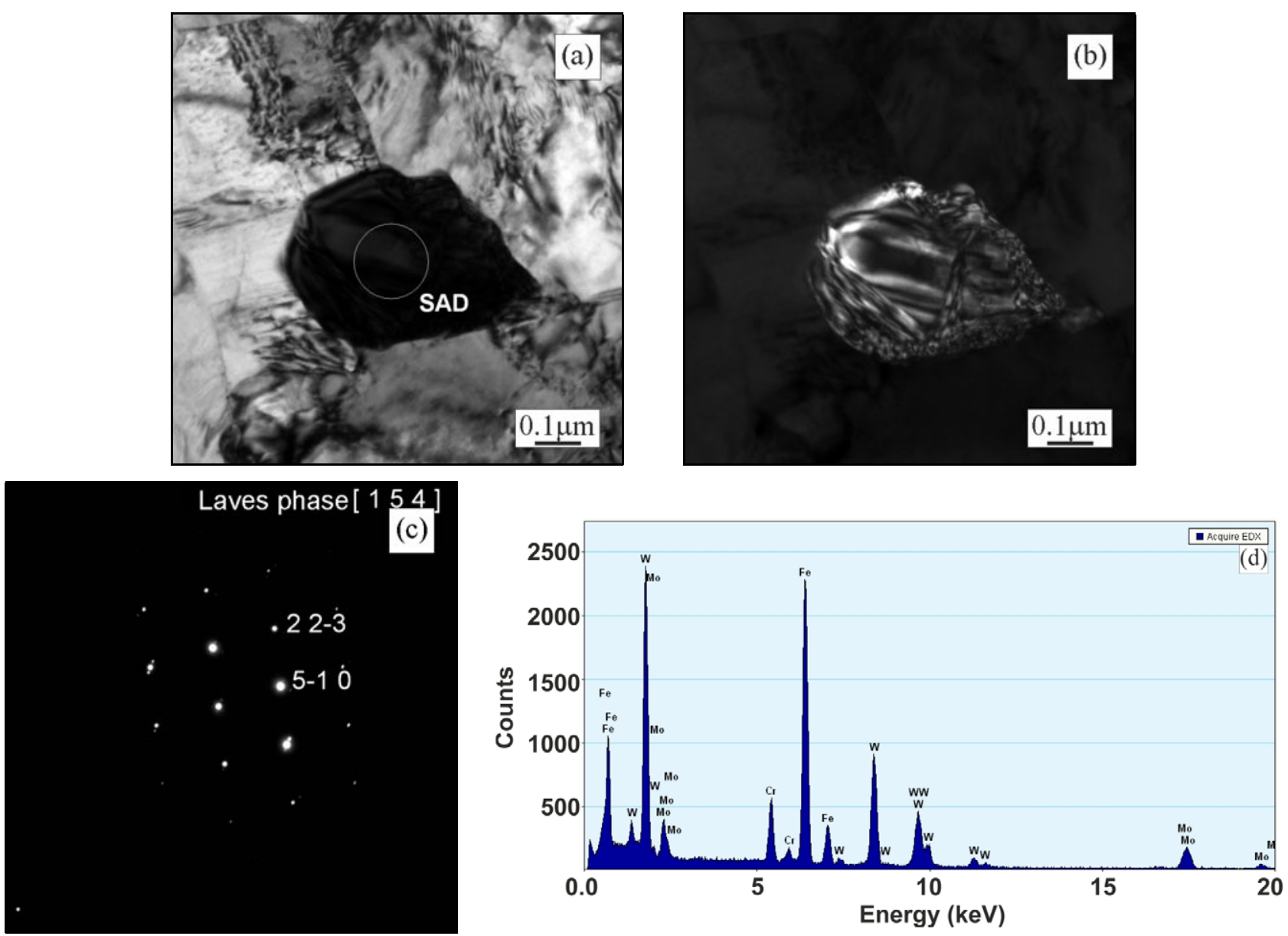

Fig. 9. Laves phase precipitates in P92 steel after 100,000 h ageing at $600{ }^{\circ} \mathrm{C}$ : a) bright field, b) dark field, c) resolved electron diffractogram of Laves phase, d) EDS analysis of Laves phase, TEM.

and size of precipitates on the former austenite grain boundaries, the main microstructural degradation mechanism in the examined steel was the process of precipitation and growth in Laves phase precipitates (Table 2, Fig. 9). The influence of Laves phase on microstructure and mechanical properties of high-chromium steels should be considered as explicitly negative. The precipitation, the increase, and the fast coarsening of thermodynamically unstable Laves phase contributes to the depletion of a matrix by substitution elements (tungsten, molybdenum) as a result of their diffusion from the matrix to this phase. It leads to an acceleration of matrix recovery and polygonisation processes - degradation of tempered martensite lath microstructure in favour of polygonised ferrite microstructure. At the same time, the depletion of a matrix by alloying elements, which are also the components of $\mathrm{M}_{23} \mathrm{C}_{6}$ carbides, slows down the growth of these carbides. In the examined steel after the longest time of thermal ageing, Laves phase precipitates with an average diameter of at least approx. $500 \mathrm{~nm}$ were observed.

The existence of chromium-rich MX precipitates revealed in the examined steel seems to indicate the possibility that Z-phase precipitates, comprised of $\mathrm{NbCrN}$ chromium nitride, occur in the microstructure. The Z-phase precipitates in $9 \% \mathrm{Cr}$ steel after long-term thermal ageing were observed by [21]. The precipitation of Z-phase results in the disappearance of finedispersion MX precipitates, which causes a sudden decrease in creep strength in $12 \% \mathrm{Cr}$ martensitic steels. However, in contrast to these steels, the impact of Zphase precipitates on creep strength in $9 \% \mathrm{Cr}$ steel is slight $[21,22]$.

The effect of long-term thermal ageing at 600 and $650^{\circ} \mathrm{C}$ on mechanical properties of P92 steel is shown in Figs. 10-14. Long-term thermal ageing of P92 steel at 600 and $650{ }^{\circ} \mathrm{C}$ and soaking times of up to $30,000 \mathrm{~h}$ had a slight impact on the decrease in mechanical properties - yield point and tensile strength - both at room (Figs. 10, 11) and elevated temperatures (Fig. 12). The insignificant decrease in mechanical properties of P92 steel after $30,000 \mathrm{~h}$ ageing, not exceeding $10 \%$, indicates very slow matrix recovery and polygonisation process - degradation of tempered martensite lath microstructure. P92 steel is characterised by metastable tempered martensite lath microstructure with high-density dislocation. The ef- 


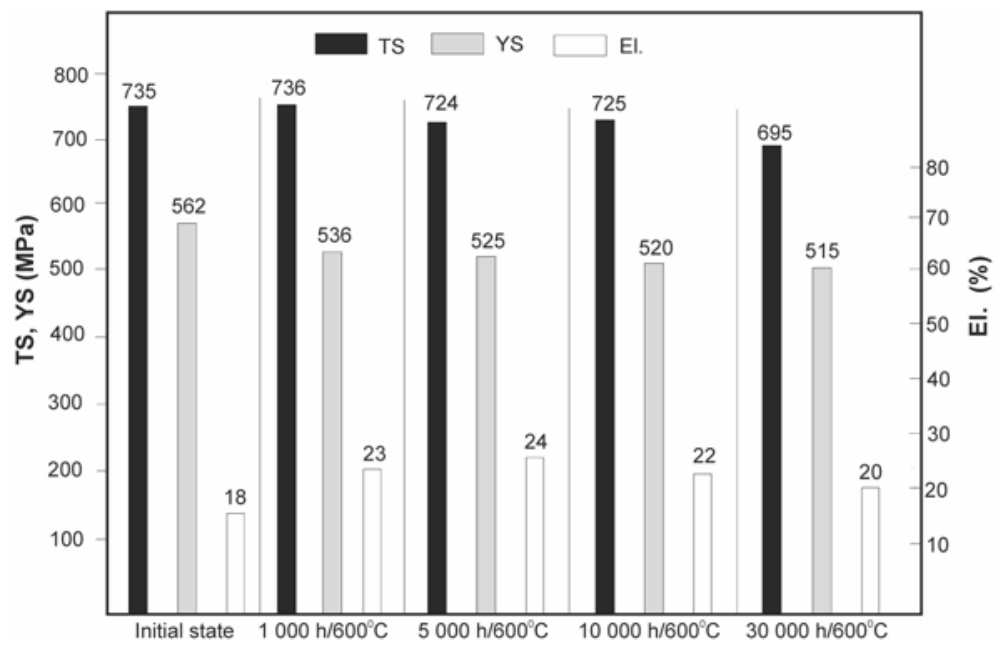

Fig. 10. Change in mechanical properties of P92 steel after ageing at $600{ }^{\circ} \mathrm{C}$.

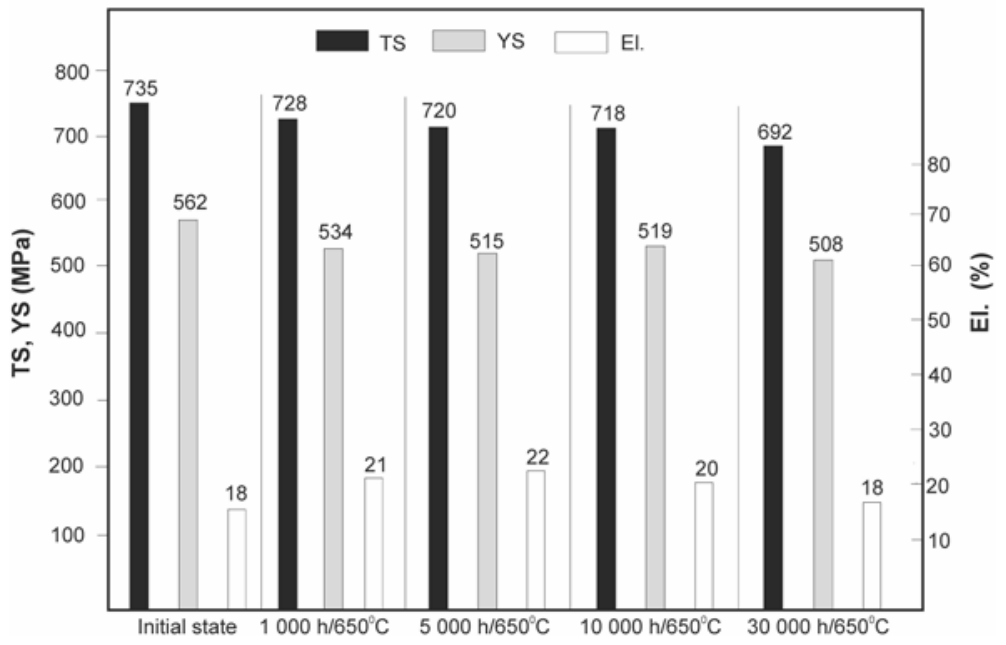

Fig. 11. Change in mechanical properties of P92 steel after ageing at $650^{\circ} \mathrm{C}$.

fect of temperature and time, and under creep conditions also of stress, will contribute, through dislocation movement, to a gradual degradation of lath microstructure and decrease in dislocation density, and in consequence to a reduction in mechanical properties.

Hence, an extremely important issue is to increase the stability of $\mathrm{M}_{23} \mathrm{C}_{6}$ carbides and/or Laves phase precipitates on the dislocation boundaries, which effectively hinders the movement of dislocation boundaries, to allow the lath substructure to be maintained and the matrix polygonisation processes to be slowed down. According to [23], strengthening caused by the refinement of microstructure with martensite lath boundaries in $9-12 \% \mathrm{Cr}$ martensitic steels is the predominating strengthening mechanism. On the other hand, a slightly higher decrease by approx. $12 \%$ was recorded for HV10 hardness (Fig. 13), which may result from coarsening of $\mathrm{M}_{23} \mathrm{C}_{6}$ carbides and Laves phase, but also from the probable presence of Z-phase

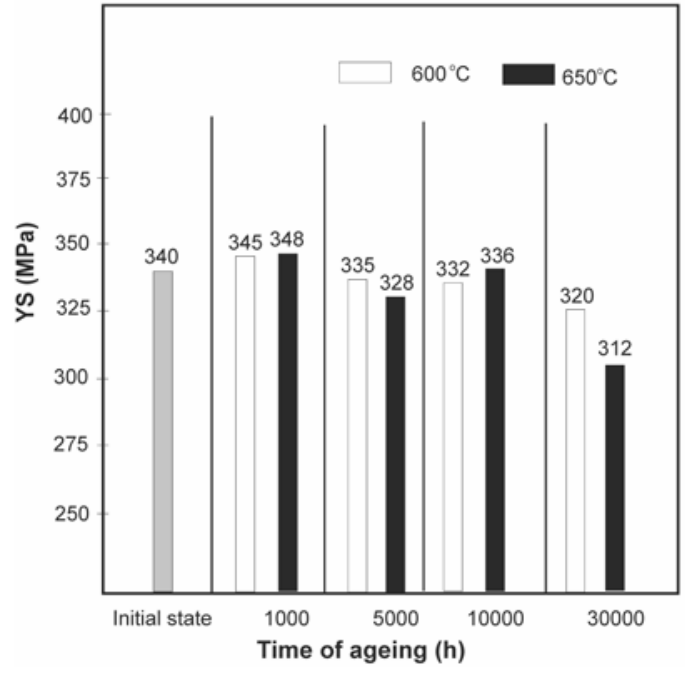

Fig. 12. Change in yield point of P92 steel at elevated temperature. 


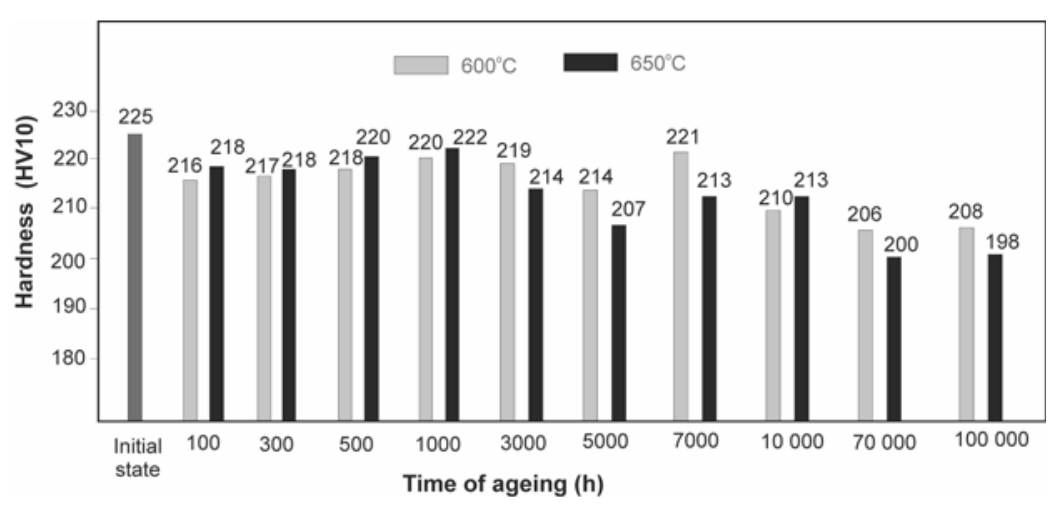

Fig. 13. Change in hardness of P92 steel after ageing for up 100,000 h.

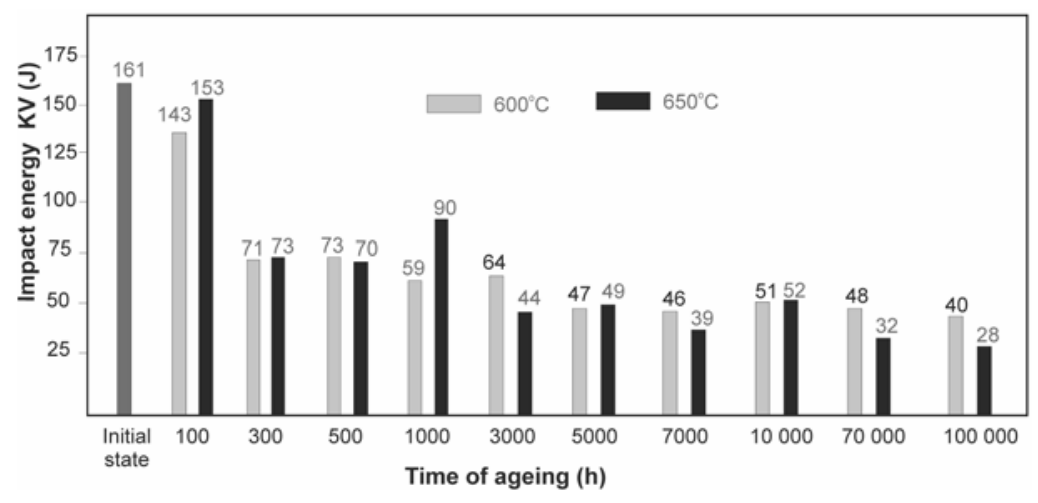

Fig. 14. Change in impact energy of P92 steel after ageing for up 100,000 h.

precipitates in the microstructure, which results in a reduction in the effect of precipitation and solution strengthening. The similar impact of long-term thermal ageing on changes in mechanical properties in $9 \%$ Cr steel was also observed in $[8,12-15,24]$.

The effect of the time of ageing at 600 and $650{ }^{\circ} \mathrm{C}$ up to $100,000 \mathrm{~h}$ on impact energy of P92 steel is shown in Fig. 14. A slight reduction in mechanical properties was accompanied by significant decrease in impact energy of the examined steel from $161 \mathrm{~J}$ in initial heat treatment condition to 40 and $28 \mathrm{~J}$ after $100,000 \mathrm{~h}$ ageing at 600 and $650{ }^{\circ} \mathrm{C}$, respectively (Fig. 14), i.e. by approx. 75 and $83 \%$, respectively, as compared to the initial heat treatment condition.

The main reason for the decrease in impact energy of the examined steel should be sought in precipitation and growth of the particles of Laves phase precipitated at the grain/lath boundaries, which is also implied by other researchers $[12,15,24]$. The decrease in ductility of the examined steel was also affected by the increase in an amount of $\mathrm{M}_{23} \mathrm{C}_{6}$ carbides precipitated at the grain boundaries, which form the socalled "network of precipitates" in places, but also the degradation of tempered martensite lath microstructure (Figs. 7, 8). According to data [24, 25], Laves phase as well as $\mathrm{M}_{23} \mathrm{C}_{6}$ carbides precipitated at the grain boundaries have a negative impact on the duc- tility of the examined steel, weakening the cohesion of grain boundaries. According to tests [25], Laves phase precipitates with average diameter higher than $130 \mathrm{~nm}$ contribute to a change in the cracking mechanism of high-temperature creep resisting steel from ductile to brittle (transcrystalline cleavable fracture) and are the main reason for the sudden reduction in creep strength of $9 \% \mathrm{Cr}$ steel.

Another possible reason affecting the reduction in ductility of the examined cast steel can be sought in segregation of admixture atoms, such as, for example, phosphorus, up to the grain boundaries or package boundaries. It is not examined in this paper, but the possibility of such a process is indicated by the test results presented in, but not limited to [26]. A significant reduction in impact energy is probably the resultant of the processes mentioned above occurring in a microstructure of the examined steel during long-term thermal ageing.

The characteristic feature observed in Fig. 14 is a very fast decrease in impact energy (by approx. $50 \%$ as compared to the initial heat treatment condition) as early as after the first 1,000 hours of ageing, and longer times of soaking result in further, but slow, gradual decrease in ductility of the examined steel. A similar course of the change in impact energy during the operation/ageing of steel was also observed in 
$[8,12]$. The trend mentioned above shows intensive precipitation/diffusion processes that in all likelihood occur within this time interval and are related, but not limited, to the occurrence of Laves phase. Literature data $[14,27]$ show that Laves phase may occur in the microstructure of tungsten-modified $9 \% \mathrm{Cr}$ steels as early as after $200 \mathrm{~h}$ ageing at $650^{\circ} \mathrm{C}$.

\section{Summary}

The examinations of microstructure and mechanical properties of P92 steel after long-term ageing at 600 and $650{ }^{\circ} \mathrm{C}$ were carried out. It was demonstrated that in addition to the matrix recovery and polygonisation process, i.e. gradual degradation of tempered martensite lath microstructure in favour of more thermodynamically stable polygonal ferrite, the main microstructural degradation mechanism in the examined steel was the process of precipitation and growth of intermetallic Laves phase. An increase in the amount and size of $\mathrm{M}_{23} \mathrm{C}_{6}$ carbides and the occurrence of Z-phase precipitates should also be rated among the above-mentioned mechanisms of microstructural degradation of the examined steel. More advanced microstructure degradation processes were observed in P92 steel annealed at $650{ }^{\circ} \mathrm{C}$.

Changes in microstructure had a slight effect on reduction in mechanical properties and hardness of the examined steel, but they resulted in a high decrease in impact energy. However, a very sudden reduction in ductility was observed already after the first few hundred hours of ageing, while further ageing resulted in a slow, gradual reduction in impact energy.

The stability of Laves phase precipitates plays a key and predominating role in the degradation of microstructure and mechanical properties of P92 steel. High susceptibility to coagulation of Laves phase - its low thermodynamic stability leads not only to a reduction in precipitation or solution strengthening but also indirectly to grain boundary strengthening of the examined steel. An increase in stability of this phase makes the processes of degradation of microstructure and mechanical properties of $9 \% \mathrm{Cr}$ steel slow down.

\section{References}

[1] Abe, F., Horiuchi, T., Taneike, M., Sawada, K.: Mat. Sci. Eng. A, 378, 2004, p. 299. doi:10.1016/j.msea.2003.11.073

[2] Sklenička, V., Kuchařová, K., Svoboda, M., Kloc, L., Kudrman, J.: In: Proceedings of 8th Int. Conf. on Materials for Advanced Power Engineering. Eds.: Lecomte-Beckers, J., Carton, M., Schubert F., Ennis P. J. Liege, Forschungszentrum 2006, p. 1127.

[3] Zielińska-Lipiec, A.: The Analysis of Microstructural Stability of Modified Martensitic Deformation. Kraków, AGH 2005.
[4] Dobrzański, J., Sroka, M., Zieliński, A.: Journal of Achievements in Materials and Manufacturing Engineering, 18, 2006, p. 263.

[5] Golański, G., Prusik, K., Wieczorek, P.: Energetics, XVIII, 2008, p. 55. (in Polish)

[6] Zieliński, A., Dobrzański, J.: Transactions of Instytutu Metalurgii Żelaza, 65, 2013, p. 42. (in Polish)

[7] Dobrzański, J.: Journal of Materials Processing Technology, 157-158, 2004, p. 297. doi:10.1016/j.jmatprotec.2004.09.047

[8] Dobrzański, J., Zieliński, A., Sroka, M.: Journal of Achievements in Materials and Manufacturing Engineering, 34, 2009, p. 7 .

[9] Yoshizawa, M., Igarashi, M., Moriguchi, K., Iseda, A., Armaki, H. G., Maruyama, K.: Mat. Sci. Eng. A, 510511, 2009, p. 162. doi:10.1016/j.msea.2008.05.055

[10] Golański, G.: Mat. Sci., 48, 2012, p. 384. doi:10.1007/s11003-012-9517-7

[11] PN-EN 10216-2. Seamless Steel Tubes for Pressure Purposes. Technical Delivery Conditions. Part 2: Non-Alloy and Alloy Steel Tubes with Specified Elevated Temperature Properties. January 2009.

[12] Golański, G., Kępa, J.: Arch. Metall. Mater., 57, 2012, p. 575. doi:0.2478/v10172-012-0061-0

[13] Tamura, M., Shinozuka, K., Esaka, H., Sugimoto, S., Ishizawa, K., Masamura, K.: J. Nucl. Mater., 283-287, 2000, p. 667. doi:10.1016/S0022-3115(00)00138-0

[14] Guo, X., Gong, J., Jiang, Y., Rong, D.: Mater. Sci. Eng. A, 564, 2013, p. 199. doi:10.1016/j.msea.2012.10.024

[15] Beak, J.-H., Kim, S.-H., Lee, Ch.-B., Hahn, D.-H.: Met. Mater. Int., 15, 2009, p. 565. doi:10.1007/s12540-009-0565-y

[16] Golański, G.: Arch. Found. Eng., 9, 2009, p. 91.

[17] Nguyen, T. D., Sawada, K., Kushima, H., Tabuchi, M., Kimura, K.: Mater. Sci. Eng. A, 591, 2014, p. 130. doi:10.1016/j.msea.2013.10.101

[18] Joarder, A., Sarma, D. S., Cheruvu, N. S.: Metall. Trans. A, 22, 1991, p. 1811. doi:10.1007/BF02646505

[19] Krol, T., Baither, D., Nembach, E.: Scripta Mater., 48, 2003, p. 1189. doi:10.1016/S1359-6462(02)00566-3

[20] Abe, F., Asano, K., Fujiwara, A.: Metall. Trans., 4, 1973, p. 1499.

[21] Danielsen, H. K., Hald, J.: VGB PowerTech, 5, 2009, p. 68 .

[22] Danielsen, H. K., Hald, J.: Energy Mater., 1, 2006, p. 49. doi:10.1179/174892306X99732

[23] Li, Q.: Mater. Sci. Eng. A, 361, 2003, p. 385. doi:10.1016/S0921-5093(03)00565-3

[24] Paul, V. T., Saroja, S., Vijayalakshmi, M.: J. Nucl. Mater., 378, 2008, p. 273. doi:10.1016/j.jnucmat.2008.06.033

[25] Lee, J. S., Armaki, H. G., Maruyama, K., Muraki, T., Asahi, H.: Mater. Sci. Eng. A, 428, 2006, p. 270. doi:10.1016/j.msea.2006.05.010

[26] Mackenbrock, M., Grabke, H. J. : Mater. Sci. Technol., 8, 1992, p. 541. doi:10.1179/mst.1992.8.6.541

[27] Cui, H., Sun, F., Chen, K., Zhang, L., Wan, R., Shan, A., Wu, J.: Mater. Sci. Eng. A, 527, 2010, p. 7505. doi:10.1016/j.msea.2010.08.013 